\title{
DO THE "HAVES" COME OUT AHEAD? WINNING AND LOSING IN STATE SUPREME COURTS, 1870-1970
}

\author{
STANTON WHEELER \\ BLISS CARTWRIGHT \\ ROBERT A. KAGAN \\ LAWRENCE M. FRIEDMAN
}

\begin{abstract}
This paper tests the hypothesis that financially and organizationally stronger parties tend to prevail in litigation against weaker parties, either because the normative structure of the American legal system has favored "the haves," or because judges' attitudes do, or because stronger parties have strategic and representational advantages in litigation. The study is based on a sample of 5,904 cases from sixteen state supreme courts, 1870-1970. According to our data, stronger parties, especially larger governmental units, did tend to achieve an advantage over weaker parties, but the advantage generally was rather small. The stronger parties' edge recurs in subsamples for different types of cases, time periods, and types of legal representation. It is attributed in part to the greater litigational capabilities of stronger parties.
\end{abstract}

The idea that parties with more power, status, or resources have advantages in litigation and adjudication is hardly new, but it has received renewed attention in the last decade. The proposition is one of the cornerstones of Black's (1976) propositions about the behavior of law, and it lies at the heart of Galanter's analysis of "Why the 'Haves' Come Out Ahead" (1974). Galanter's essay describes why parties with greater resources, usually "repeat players" in the legal system, might tend to win, and it has stimulated further research on the outcomes of court cases (Galanter, 1975).

This paper was presented at the Annual Meeting of the Law and Society Association, Chicago, May 29-June 1, 1986. It profited from suggestions made when it was presented to a Law, Economics, and Organization Workship at Yale Law School, New Haven, in April 1985, and most particularly from critiques by Robert Ellickson and George Priest. Further helpful points were made when it was presented at the Center for the Study of Law and Society at the University of California, Berkeley. Special thanks, too, to Thomas Davies for his detailed and insightful criticisms, only some of which we have been able to respond to adequately. The original research was supported by the $\mathrm{Na}$ tional Science Foundation Program in Law and Social Science Grant No. GS-384-13.

LAW \& SOCIETY REVIEW, Volume 21, Number 3 (1987) 
We wish to use the general framework of Galanter's analysis to explore outcomes in cases decided by state supreme courts. His argument about the advantages enjoyed by the "haves" extended beyond legal outcomes in decided cases. "Repeat players," who tend to be "haves," will come out ahead, he suggested, because they are likely to be adept at conforming their behavior, contracts, and claims to the requirements of the law; hence less experienced individuals ("one-shotters") with grievances will be deterred from initiating legal action against repeat players or contesting legal claims made by them. Secondly, Galanter contended, "haves" can better afford the delays, discovery expenses, and other opportunity costs associated with litigation, and are less compelled to accept disadvantages in pretrial settlements. Thirdly, in Galanter's view repeat players have strategic advantages in shaping the evolution of legal doctrine because they have the resources to settle cases that threaten to lead to adverse precedents and to advance arguments and push cases that might result in rulings that promote the interests of the "haves."

Galanter also implied, however, that the "haves" would tend to come out ahead in adjudicated decisions in a quantitative sense, winning more often than "one-shotters." They would do so, he contended, by virtue of their greater legal experience, case-selecting ability, and financial resources to pour into continuous, high-quality legal representation. We will focus only on this aspect of Galanter's theory, that is, on quantitative case outcomes in state supreme court decisions viewed in the aggregate. Since Galanter's essay was mostly concerned with trial courts, whether the factors that presumably favor the "haves" in trial forums apply with equal force in appellate courts remains an open question. As we will show, one can easily construct plausible hypotheses suggesting that the "haves" will not come out ahead in state supreme courts.

\section{THE STUDY}

To examine a variety of features of the history of state supreme court actions between 1870 and 1970, we used a sample of sixteen states (one-third of the total if we exclude Hawaii and Alaska, which became states only toward the end of our one-hundred-year period). To pick these sixteen, we divided the forty-eight states into clusters that were, for most of those hundred years, most alike in population, industrialization, urbanization, per capita income, racial composition, legislative innovativeness, and other measures likely to affect the legal busi- 
ness of the state court system. ${ }^{1}$ One cluster was made up of Plains states such as Kansas, Nebraska, and the Dakotas; another consisted of urban, industrialized states. A third cluster included the Southern states; the Rocky Mountain states formed another distinct group. From each cluster we selected states randomly, in numbers proportionate to the size of the cluster. The sixteen chosen are, alphabetically, Alabama, California, Idaho, Illinois, Kansas, Maine, Michigan, Minnesota, Nevada, New Jersey, North Carolina, Oregon, Rhode Island, South Dakota, Tennessee, and West Virginia.

We sampled all state supreme court opinions that were at least one page in length for each of these states in twenty-one sample years: $1870,1875,1880$, and so on, through $1970 .^{2}$ From the opinions in each sample year, we randomly drew eighteen cases from each of the sixteen courts, producing a total of $5,904 .{ }^{3}$ One member of a team of ten law students then read each case, recording its procedural history, the nature of the parties, the court's decision, and the area of law that underlay the plaintiff's claim. 4 We believe the result is a representative sample of cases, reliably coded. 5

In our first report (Kagan et al., 1977), we traced the shifting areas of law that have dominated the work of the courts at various times, and examined the relationship between the changing nature of the cases and the changing character of the society from which they were drawn. In our second report (Kagan et al., 1978), we traced the evolution of state appellate court

1 Measures taken from census data were assembled by Hofferbert (1968) and made available through the University of Michigan Consortium. The measure of legislative innovativeness was developed by Walker (1969).

2 In addition to very short memorandum opinions, we excluded from our sample opinions on rehearing and opinions denying motions for rehearing. We also excluded, necessarily, decisions issued without opinion (or without published opinion) and decisions granting or denying petitions for review.

3 Our target was a sample of 6,000 cases (budget and time prevented anything much larger), which worked out to 18 cases from each of 21 sample years for 16 states. The actual sample turned out to be 5,904 cases because Idaho and South Dakota did not become states until 1890, and thus we had only 17 sample years for those courts.

4 The reader further noted any constitutional issues, the presence of concurring or dissenting opinions, the length of the opinion, the number and type of authorities cited, and how often the case was subsequently cited in Shepard's Citations. Twenty \% of the sample cases were initially doublecoded; hundreds more were reread and recoded in the course of "cleaning" the data. See Cartwright, 1975.

5 Peter Harris, who is examining the interstate citation patterns for these cases, reports in a personal communication that citation patterns in our 16 sample states are extremely close to the patterns for the thirty-two nonsampled states. For example, the mean number of subsequent citations received by the group of 126 sampled opinions in our sample state courts is 400.7 ; for nonsampled state courts the number is 395.9 , a difference of less than $2 \%$. 
structure, described how the courts wrestled with caseload pressures, and assessed the consequences of supreme court discretion to select its caseload. In a third report (Friedman et al., 1981), we examined the changing patterns of citation in court opinions, including the length of the opinions, the rate of dissenting opinions, and citations to other states. ${ }^{6}$ In short, our interest has been in drawing a broad portrait of the functioning of state supreme courts and explaining how that function has changed over the past century.

\section{HYPOTHESES}

In supreme court litigation, as elsewhere in the legal system, it is often possible to characterize one of the two contending parties as the stronger in the sense of having more financial or organizational resources. Both common sense and conventional wisdom suggest that stronger parties will win more often. Against that assumption, however, we must first consider a well-known characteristic of appellate courts-a propensity to affirm the decisions of lower courts (Davies, 1982; Howard, 1981; Yale Law Journal, 1979; Canon and Jaros, 1969; Meeker, 1984). During the 1870-1970 period, our sixteen state supreme courts decided against the appellant and affirmed the lower court decision in about 60 percent of cases decided with full opinion. Only in the first of our twenty-one sample years, 1870 , did the sixteen-state affirmance rate fall below 50 percent, and since the turn of the century it never fell below 59 percent. Only the West Virginia court consistently reversed lower courts more often than it affirmed, posting an affirmance rate of 44.8 percent.

The tendency to affirm may reflect legal doctrines-such as the "harmless error rule" (Traynor, 1970) and the "substantial evidence rule" and norms against deciding issues not raised at trial (Davies, 1982) - that enjoin appellate judges to defer to the decisions of trial judges and juries unless "serious" or "prejudicial" errors of law have been committed. Uncertainty concerning the precise meaning of those doctrines or inconsistencies in their application may induce many lower court losers and their lawyers, even sophisticated ones, to overestimate their chances on appeal. ${ }^{7}$ Moreover, it may be quite rational for

6 See also Harris, 1985a and b. Related reports describe career backgrounds of state supreme court judges (Kagan et al., 1984) and analyze reasons for the declining debt collection litigation in state supreme courts (Kagan, 1984).

7 Davies pointed out to us that the "harmless error rule" was introduced, or at least expanded, early in the twentieth century, largely because of 
lower court losers to appeal even if their perceived chances of winning fall short of fifty-fifty. In some cases, the lower court loser has so much at stake that even a low probability of obtaining a reversal justifies the incremental cost of an appeal. In other cases, the lower court loser may appeal to impose greater delays, costs, and uncertainties on the lower court winner. ${ }^{8}$ Not surprisingly, affirmance rates have tended to be lower for the few state supreme courts that had full discretion to select their cases from petitions for review and hence to reject those with limited merit or significance; 9 affirmance rates were higher for most state courts, which had to accept even clearly unmeritorious appeals taken "as of right."

We do not wish to exaggerate the supreme courts' antiappellate posture. Forty percent of the appealed decisions, after all, were overturned. But one must recognize the basic propensity of state supreme courts, quite apart from any consideration of party strength, to affirm more often than they reverse. We must ask, therefore, not only how often parties with greater financial and organizational resources (the "haves") won in an absolute sense, but also whether they were better able than other parties to buck the basic tendency of appellate courts to affirm. We begin by spelling out the various reasons the "haves" might enjoy greater success, but go on to consider alternative hypotheses that suggest that they might not.

claims that the rates of late-nineteenth-century reversals were too high and that reversals were being made for insubstantial, "technical" reasons. See Davies, 1982: 578, 601; Friedman, 1973, 131-33, 347-48. But see also Friedman and Percival, 1981: 287. This may help explain the increase in our sixteen-state affirmance rate from $55.1 \%$ in $1870-1900$ to $61.8 \%$ in $1905-1935$. It was about the same in $1940-1970(62.5 \%)$.

8 Many of the benefits flowing to "haves" at the lower court level, as recounted by Galanter (1974), actually are benefits enjoyed by defendants of any kind, that is, the delays, litigation expenses, and opportunity costs they can impose on plaintiffs simply by insisting on litigation. Most defendants are "haves" in the sense that they have what plaintiffs can obtain only by shouldering the burdens and anxieties of litigation. Thus even rich repeat players, such as creditors with a good legal case, can often be induced to settle for less by recalcitrant smaller debtors who decline to default. See Leff, 1970; Kagan, 1984. Similarly, lower court losers often can obtain significant advantages, and sometimes even the possibility of a favorable settlement, by appealing, which forces the lower court winner to litigate further to obtain what he thought was his-a judgment.

9 Beginning in 1872, West Virginia's constitution allowed appeals to the state supreme court only after the court "shall have examined and considered the record and assignment of errors, and is satisfied that there is error in the same, or that it presents a point proper for the consideration of the Supreme Court of Appeals." Under this rule, the court rejected many petitions for review. See Kagan et al., 1978: 973-974. Similarly, the New Jersey and California Supreme Courts developed high reversal rates in the 1950-70 period, as they were granted strong case-selecting discretion (ibid., pp. 994-995). 


\section{A. Why the Stronger Party Should Come Out Ahead}

Three sets of reasons-relating to the law, judicial attitudes, and characteristics of parties and their lawyers-may be advanced to support the proposition that stronger parties should win more often. First, there might be a normative tilt of the law toward the stronger interests. When the legally correct ruling is unclear, as it often is in supreme court litigation, judges are enjoined to look to the fundamental principles and policies that presumably underlie specific rules of law or precedents (Dworkin, 1967). In a market economy such as ours, fundamental rules of law are designed to protect property and written contracts and to sustain the basic health of socially important business enterprises. Judges complying with the spirit of those laws might tend to resolve legally doubtful issues in favor of business parties. Similarly, many principles of administrative law are designed to protect the efficiency and authority of democratically elected governments; thus in hard or doubtful cases involving challenges to governmental action by individuals (e.g., taxpayers, property owners, licensees) supreme court judges, who are, after all, part of the apparatus of government, might feel constrained to rule in favor of the government party. ${ }^{10}$ Moreover, given a body of law that on balance is tilted toward business or government interests, or even one that is "neutral" (whatever that might mean), if lower court judges and juries are, as is likely, susceptible to pleas for compassion and consideration of the equities of particular cases and thus tending to favor the "underdog" (Chin and Peterson, 1985), stronger parties would win more often on appeal in supreme courts committed to dispassionate adherence to the law.

Second, the tribunal itself may be biased toward the stronger parties. Judges do not in general come from working class backgrounds; and in any case they have moved into the ranks of the relatively well-to-do when they are on the bench. Consciously or unconsciously they may accord greater legitimacy to established interests and doctrines by virtue of attitudes acquired in their legal careers and social relationships. ${ }^{11}$

10 In discussing this "normative-tilt-of-the-law" hypothesis, we stress its role in hard or doubtful cases because when laws favoring stronger parties are rather clearly controlling on the facts of a case, we assume that weaker parties would not waste their time and money in appellate litigation.

11 Approximately one-third of the state supreme court judges in our 16 states in the 1900-1970 period had served as public prosecutors before joining the judiciary, and another one-third had held other elected political office. About half had served as lower court judges for 5 years or more before reaching the state supreme court. Thus they might be characterized, by and large, 
They may be philosophically attracted to abstract principles of individual responsibility that the weaker parties less often measure up to. And as they are more removed from direct contact with "underdog" parties than lower court judges, supreme court justices may be more inclined to give a restrictive construction to legislative enactments designed to shift costs to businesses or to benefit small debtors, consumers, and criminal defendants.

Third, the stronger party typically can command greater litigational resources, which include both financial resources and experience in dealing with the legal system. As repeat players, governmental and business organizations can, as $\mathrm{Ga}-$ lanter puts it, "play for the rules" (1974), settling lower court cases that they fear they might lose on appeal and contesting those in which the facts or law provide a particularly good chance of victory for the stronger party at the supreme court level. In making these strategic decisions, richer, more experienced parties presumably more often have the counsel of lawyers experienced in appellate litigation. They also can pay for more hours of legal and factual research in each case, have their lawyers devote more effort to establishing a trial court record that will facilitate arguments on appeal, and thus end up with briefs that are more imaginative and informative. ${ }^{12}$

\section{B. Why the Weaker Party Should Come Out Ahead}

It is, however, possible to frame alternative hypotheses that argue that the weaker party should enjoy greater success. First, throughout much of this century, the law might be characterized as gradually moving more and more toward favoring weaker over stronger parties. It could be argued that beginning with the Populist Era, successive reform moments, reflecting the general social trend advocating equality and the welfare state, have pushed the underlying principles of American law away from support for property and contractual rights toward greater protection for workers, debtors, consumers, and the unfortunate (Friedman, 1985). In doubtful cases, therefore, supreme court judges, searching for the underlying spirit or pol-

as having been part of the governmental establishment. On the other hand, state supreme courts have by no means been dominated by graduates of elite law schools or large, urban firms, suggesting that representation on the courts of the business establishment has been somewhat weaker. See Kagan et al., 1984.

12 Some evidence from administrative agency appeal systems indicates that the stronger parties are better able to present their case as more important, more special, and more demanding of the tribunal's thoughtful consideration. See Kagan, 1978: chap. 9. 
icy priorities of reform legislation and judicial precedents, might more often feel compelled to find for the weaker, smaller, or otherwise less protected parties.

Second, with respect to judicial bias, state supreme court judges have either been popularly elected or appointed after a politically active career (Kagan et al., 1984). Hence one might expect that a significant number reflect the persistent populist strain in American politics, that is, the support of the little man against the big man, or the individual against the corporation. Most state supreme court judges served as trial court judges at least for a time. Furthermore, at least a third were once politicians (ibid.) and thus not the insular professional elite sometimes associated with European judiciaries. Moreover, the American judicial style has often been seen as pragmatic, or more oriented to substantive justice than to legalistic application of rules. Appellate judges may therefore have a tendency, in Shapiro's (1975: 352) words, to "keep clawing their way back toward the facts" and do justice in each particular case. Those facts often may lead to support for the weaker of the two parties.

Third, the weaker party might tend to win despite the stronger parties' apparent edge in litigational resources because financially strong parties who lose in trial courts will perhaps more often bring unmeritorious appeals for purposes of delay. In addition, the larger party-a corporation with a legal department, for instance-may be so organized that the marginal cost of another appeal is low. Conversely, other factors equal, any given case is likely to mean more to the weaker of the two parties, who may therefore try to harness their resources more efficiently and be less likely to support frivolous appeals. We call this the "more crucial outcome" hypothesis.

\section{Why No One Should Systematically Come Out Ahead}

There is a third logical possibility: There should be no difference in outcome as a function of party strength. First, the conflicting and essentially unresolvable versions of the "normative-tilt-of-the-law" hypothesis reflect the difficulty of generalizing about the substance or spirit of the law in post-1970 America. Periodic reform movements, led by the Populists, Progressives, New Dealers, and 1960s liberals, have surged up to leave their imprint on the law, more strongly in some states than in others, often to be followed by periods of conservative reaction, again more strongly in some states than in others. Characterizing the whole is like the proverbial blind man's at- 
tempt to describe an elephant. Some laws and judicial precedents favor "haves," some favor "have nots," and many represent complex compromises that are hard to characterize. The diversity of legal roles in a market economy, moreover, confounds attempts to label many areas of law as favoring particular interests. A corporation, for example, may be either plaintiff or defendant in an accident case, may be either creditor or debtor at various times, may sue the government or be sued by it, and so on. Hence the philosophy behind particular rules of law will not systematically compel judicial support for "corporate" interests in hard cases, for these very interests are diverse and conflicting over time. Consequently, one might hypothesize, legal resolutions of the complex doctrinal and technical procedural issues that bulk so large on supreme court dockets are unlikely to reflect a systematic bias along the "have"-"have not" dimension.

With respect to judicial attitudes, the radical legal realistone who holds that appellate judges decide not in response to legal rules but in response to the dictates of their inner values and personalities as triggered by features of particular casesmight hypothesize that these influences are so numerous, varied, subtle, and unsystematic that no predictable patterning of results will emerge. Although class bias is one of the possible influences, American modes of recruitment to the bench are so diverse and shifting and the system is so penetrable and pluralistic that the various biases are likely to cancel each other out over time. A modified legal realist might hold that there will indeed be systematic differences in outcomes as a function of the attitudes of judges. A liberal court, for example, will favor the criminal defendant and the civil case "underdog," while a conservative court will reverse that process. Outcomes will thus depend on the composition of the bench, which, in turn will depend on the appointive or elective process. Political winds in the United States, however, have been variable. Thus there will be a swing back and forth between periods in which the stronger parties may be favored and periods in which the weaker may be favored. This argument, then, agrees with the hypotheses that suggest outcomes will not be equal at any given time. As we examine the historical record, there will be ebbs and flows in the direction of one or another type of party. But there is no clear basis for predicting which orientation will obtain most of the time. Thus, overall results will probably be indifferent as between the parties.

Finally, there is the "rational actor" hypothesis, which would contradict the notion that class-related imbalances in liti- 
gational capacity will systematically bias results. At the level of the highest forum in the state, this hypothesis assumes, otherwise weak parties want and obtain reasonably good lawyers. Hence really vast differences in the quality of counsel and strategic calculation are less likely than at the lower court level. ${ }^{13}$ Lawyers (and their parties) are rational actors trying to make sensible predictions of what the courts will do, taking into account all the factors of judicial bias, legal philosophy, and strategy discussed above. If a case, viewed in relation to lawyers' assessments of the tilt of the law and the known dispositions of particular appellate judges, seems at all one-sided in either direction, there will be strong incentives to settle out of court because the costs of litigation are high, and neither party has an interest in pursuing it unless there is a substantial probability of winning. They will move ahead only in cases in which both parties, as advised by counsel, feel that there is a substantial possibility of winning. But those will indeed be very tough and very close cases, offering little basis for predicting which side will win. ${ }^{14}$ Under these circumstances, there is no basis for predicting that any particular kind of party will systematically come out ahead.

Thus, the advantage of the "haves" in lower court litigation and adjudication may dissipate at the level of the highest court. There are plausible reasons to suppose that weaker parties may occasionally have an edge there, and perhaps even more reason to believe that party strength will not predict outcomes. With this full range of possibilities in mind, we turn to the empirical data.

\section{EMPIRICAL RESULTS}

\section{A. Distinguishing "Haves" from "Have Nots" and "Winners" from "Losers"}

In the researcher's ideal world, valid and reliable indicators of basic concepts are routinely forthcoming from whatever data source is under study. In actuality, of course, that is rarely the case, and it is definitely not the case in this instance. If we had

13 Marvell, in a recent study of one state supreme court, interviewed judges about how often one attorney does a much better job than his opponent. He reports (1978: 37) that "the judges rarely stated or implied that there is a substantial imbalance in the majority of appeals, and several said it is quite uncommon." In Marvell's interviews, appellate judges disagreed on the importance of quality of advocacy in affecting outcomes.

14 See Priest and Klein, 1984. In his study of supreme court litigation in a northern industrial state (in which the court had case-selecting discretion), Marvell (1978: 66) found most attorneys, particularly in civil cases, rather incapable of predicting how the court would decide cases in which they were pre- 
detailed data on the income levels of individual litigants, or even rough approximations through such variables as occupational status, we might be able to test the "haves" versus "have nots" hypotheses directly. But we are restricted to the supreme court opinions themselves, and specific information about the wealth of the parties is usually not available. Similarly, when organizations are opposing parties, we rarely have enough information to classify one litigant unambiguously as the party with greater resources. In this sense, a full and complete test of the hypotheses is not now possible. We have therefore adopted the pragmatic solution of assigning parties to general classes, and then making assumptions about which class is usually stronger or weaker. Thus even though some tenants are richer than their landlords, we assume that landlords are financially stronger and hence that any particular landlord in an eviction case is the stronger party.

Using that approach, we developed four ways of examining relative resources. First, we were usually able to distinguish between individual litigants, individual business proprietorships, business corporations, and government parties. Although some individual claimants might be stronger than some business organizations, on the average organizations will have more resources, and we feel safe in designating them, relatively speaking, as "haves." Similarly, individuals are generally weaker in resources than units of government. When business parties and governmental parties contend, we assume that bigger is stronger-that larger business organizations are stronger than small towns, for example, or that city and state governments are stronger than business proprietorships. When business and government parties of generally similar size contend (business proprietors against small town government parties, or city and state governments against business organizations), we assume the governmental parties will generally be stronger, for they are more likely to be repeat players in the system.

As a second set of indicators, we took four types of business parties that seem especially likely to be repeat players and to have substantial financial and legal resources at their disposal: railroads, banks, manufacturing companies, and insurance companies. We then tried to see how well they did in litigation against other parties. We feel confident that in most cases they

paring arguments, and unknowledgeable about individual supreme court judges' predilections. Indeed, Marvell reports, the judges' law clerks, when asked if they could predict, after reading the briefs, how the court would decide, generally said they had great difficulty in doing so (ibid., p. 12). 
were "haves" relative to individuals and most other business parties although not necessarily with respect to governmental units.

As a third test, we restricted our comparison to cases arising within certain specific areas of law. This allowed a more focused test of the impact of differences in party strength.

Finally, we considered cases involving certain specific role relationships that can be related to presumed financial strength and litigational experience. For example, we concentrated on cases in which creditors faced debtors; the creditor is assumed to have had greater resources most of the time. For the same reason, we selected cases in which a landlord faced a tenant, an employer faced an employee, and a company faced an individual in workplace accident cases, assuming that the landlord, employer, or company was the stronger.

These rules seem reasonable as a first approximation, absent more direct and powerful measures of party strength. It must be remembered that we are testing hypotheses about relative strength of resources. Appellate litigants, except for prisoners, are likely to have some access to resources. It may turn out that relative wealth is unimportant above a certain minimum; in this case we should find no differences in outcomes that favor the "haves." In any event, it should be clear that we are not comparing "haves" and "have nots" in any absolute sense; rather we are examining differentials in relative strength between categories of parties and their possible effects.

Three complications remain. First, what happens when parties do not fall naturally into one or another category? Many suits have multiple parties; of two appellants, for example, one might be an individual and another a business. At first, we were inclined to examine only "pure" cases-those with a single, easily classified party on both sides. But that strategy eliminated about half the cases and seemed unduly restrictive. Consequently, when multiple parties were appellants (or respondents), we treated them as one party, coded according to the strongest member on their side. For example, if an individual and a business corporation both appealed a lower court ruling, we coded the appellant as a business organization. If two individuals appealed against a state agency, we coded the case as "individual" versus "state government."

The second problem was how to tell "winners" from "losers." In most cases the final judgment clearly favors one side. A few cases go back to the lower court without final decision and without a clear victory for either party. We excluded 
all cases of ambiguous result, just as we had to exclude those in which the nature of the parties was too confused, ambiguous, or complex. But the loss is small. Application of both decision rules still left over 5,300 cases for analysis. Finally, in determining "winners" and "losers," we looked at who won the appeal in its most immediate sense, without attempting to view the appeal in some larger context. For example, in coding outcomes we ignored the possibility that an appellant who sought primarily to postpone the day of judgment might have "won" in terms of successfully obtaining a profitable delay, although the legal grounds for its appeal were rejected. Similarly, we ignored the possibility that the loser on appeal nevertheless may have "won" in the sense of persuading the court to cast the issues narrowly and reject the opponent's request for a major change in legal doctrine. Thus we do not attempt to assess whether the policies articulated by state supreme courts tended to favor "haves" or "have nots" in general or in particular cases. ${ }^{15}$

The third complication concerns the grouping of cases for purposes of analysis. Ideally, one would compare the fate of stronger and weaker parties in different state courts, which vary by political complexion, caseload, degree of case-selecting discretion, and level of dissensus. One would also divide the court-by-court analysis into ten or fifteen-year periods. Simultaneously, one would introduce controls to see whether the results differed by type of legal issue. Unfortunately, despite the size of our sample, carving it into such finely tailored subsamples, however desirable in principle, produced cell sizes that were so small as to threaten reliability, and tended to complicate an already long and complex story. We chose, therefore, to analyze the sixteen state sample as a whole, one that was reasonably representative of all fifty state courts taken as a block. Thus in this article we forgo the opportunity to compare the fate of "haves" and "have nots" in, for example, large, urbanized states versus smaller, rural states or in Northern states versus Southern states or caseload-selecting courts versus low discretion courts, even though such analyses would undoubtedly reveal differences that would qualify our aggregate-level conclusions.

Similarly, for the most part we analyze the data in terms of

15 Moreover, as suggested earlier, by concentrating on results in decided cases, we excluded all cases in which an appeal was dropped or settled prior to the court's decision and in which the court declined to accept a petition for review (a common phenomenon in a few of our 16 courts, mostly in more recent decades). 
the years from 1870 to 1970 (although differences over time in public law and private law cases are presented in Part IV). In consequence, our results may mask significant variations from the sixteen-state, one-hundred year mean in some states in some periods, in some particular areas of law, or in two sets of courts that diverged in opposite directions. Nevertheless, we believe that as a first test of how ostensibly stronger and weaker parties have fared in state supreme courts, it is both interesting and valid to view the courts and the period as a whole.

\section{B. Individuals, Organizations, and Governments as Contending Parties}

We begin our examination by dividing all our cases into five categories, namely individuals, business proprietors, business organizations, small town governments, and city or state governments, and observe how each fared in litigation against the other types. ${ }^{16}$ The full results appear in Table $1,{ }^{17}$ which shows or makes possible four measures:

1. The appellant success rate for each type of party, as indicated by the total percentage for each row; individual parties, for example, had an overall success rate as appellants of 38.5 percent, compared with 41.6 percent for business organizations.

2. The total percentage at the bottom of each column reveals their opponents' appellant success rate; thus when individuals were respondents, their opponents had a 40 percent success rate, whereas business organizations as respondents held their opponents to a 38.5 percent success rate.

3. A combined success rate calculated by aggregating each party's results as appellant and respondent; this rate is affected by the frequency with which a type of party was appellant (a low success rate en-

16 At this stage in the analysis, individual parties include both "pure" individuals and those instances in which the real party at issue may be a larger organization representing that individual-an insurance company in tort claim cases, for example. In the category "Government, City or State," we included subunits of state governments (e.g., regulatory and tax collection agencies, workers' compensation tribunals) and of the three largest cities in each state, plus the capital city if it was not one of these. Although most criminal cases were initiated by municipal or county governments, the state attorney general's office typically represented the prosecution at the supreme court level, and we coded the state government as the litigating party (typically, the respondent). The small town government category includes units of smaller cities and county governments, including county sheriffs' offices (common litigants in cases concerning execution of judgments).

17 We have reported a statistical test, the significance of Yule's $Y$, to summarize the results in each table. But we will also discuss interesting and suggestive patterns in particular cells (which by themselves may or may not be statistically significant). Thus we present and talk about the data in its raw "percentage difference" form. 


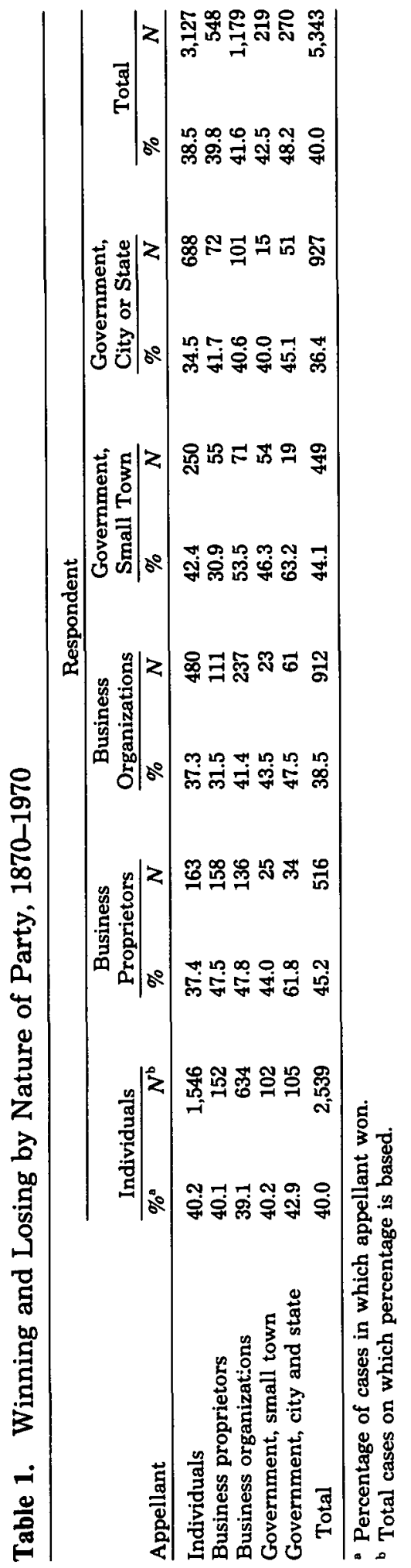


Table 2. Success Rates by Nature of Party, 1870-1970

\begin{tabular}{|c|c|c|c|c|c|c|}
\hline Type of Party & $\begin{array}{c}\text { Success } \\
\text { Rate as } \\
\text { Appellant }\end{array}$ & - & $\begin{array}{l}\text { When } \\
\text { Respondent, } \\
\text { Opponents' } \\
\text { Success Rate }\end{array}$ & $=$ & $\begin{array}{c}\text { Net } \\
\text { Advantage }\end{array}$ & $\begin{array}{c}\text { Combined } \\
\text { Success Rate as } \\
\text { Appellant } \\
\text { and Respondent }\end{array}$ \\
\hline $\begin{array}{l}\text { Government, } \\
\text { city and state }\end{array}$ & $48.2 \%$ & - & $36.4 \%$ & $=$ & $+11.8 \%$ & $60.2 \%$ \\
\hline $\begin{array}{l}\text { Business } \\
\text { organizations }\end{array}$ & $41.6 \%$ & - & $38.5 \%$ & $=$ & $+3.1 \%$ & $50.2 \%$ \\
\hline Individuals & $38.5 \%$ & - & $40.0 \%$ & $=$ & $-1.5 \%$ & $48.1 \%$ \\
\hline $\begin{array}{l}\text { Government, } \\
\text { small town }\end{array}$ & $42.5 \%$ & - & $44.1 \%$ & $=$ & $-1.6 \%$ & $51.5 \%$ \\
\hline $\begin{array}{l}\text { Business } \\
\text { proprietors }\end{array}$ & $39.8 \%$ & - & $45.2 \%$ & $=$ & $-5.4 \%$ & $47.1 \%$ \\
\hline
\end{tabular}

terprise) rather than respondent (a higher success rate, on average).

4. To offset that bias, we compare the appellant success rate with the opponents' appellant success rate to calculate a net advantage, which indicates whether each type of party did better or worse than its opponents in overcoming the overall tendency of supreme courts to affirm. For individual parties, for example, the appellant success rate minus their opponents' appellant success rate produces a net advantage of -1.5 percent, indicating that they did slightly worse than their opponents.

The results for each of these measures are summarized in Table 2. Looking first at the appellant success rate, we see that as appellants, both stronger and weaker parties lost more often than they won. But if the supreme court system was tilted against appellants, the stronger interests tended to do somewhat better than the weaker ones. Larger government units won 48.2 percent of their appeals, small governments 42.5 percent, and business organizations 41.6 percent, while business proprietors (39.8\%) and individuals (38.5\%) lagged behind.

A similar pattern is reflected in the combined success rate. City and state governments won in 60.2 percent of their appearances in supreme courts, which was considerably more than small government parties $(51.5 \%)$ and business organizations $(50.2 \%)$, which in turn did slightly better than individuals (48.1\%) and small businesses (47.1\%).18

The net advantage figure, which disregards the frequency

18 The high combined success rate of larger government parties, it might be pointed out, reflects the fact that they were in the difficult appellant role in only $29.1 \%$ of their cases (as compared with $56.5 \%$ for business organizations, $55.2 \%$ for individuals, $\mathbf{5 1 . 5 \%}$ for business proprietors, and $\mathbf{3 2 . 8 \%}$ for small governments). 
with which a party type was in the appellant or respondent role, may serve as a better indicator of whether the courts favored the parties with greater resources. Here, too, the thesis that the stronger party should prevail receives some support. City and state government parties did best not only as appellants, winning 48.2 percent of their cases; as respondents, too, they did better than any other type of party, holding their adversaries to a $36.4 \%$ success rate. Thus the net advantage for city and state governments was 11.8 percent. ${ }^{19}$ Business organizations did next best, with a margin of 3.1 percent over opponents. Individuals and small town governments occupy the third and fourth categories, respectively, doing 1.5 percent and 1.6 percent more poorly than their opponents. The bottom of the order is occupied by business proprietors, whose success rate as appellants (39.8\%) was some 5.4 percent less than that of their opponents when the proprietors were respondents $(45.2 \%) .{ }^{20}$ Thus ranking the parties by their presumed strengths and resources does provide a partial ordering of the differential success rates, but individual litigants did better than predicted by the hypothesis that the "haves" should prevail.

The marginal distributions in Table 1 and the net advantage figure based on them in Table 2 include cases in which a party confronted another party in the same category; this occurred in roughly 40 percent of cases, as reflected in the diagonal of Table 1. We are more interested, therefore, in the interactions between specific categories of parties than in the marginal distributions. For example, in the 688 cases in which individuals were appellants against city and state governments,

19 It is significant that the advantage of larger government parties stemmed not only from their apparently greater selectivity in choosing which cases to appeal (they were appellants less often and had a higher appellant success rate than other types of parties), but also from their greater success in repulsing appeals by others. Assuming that appellants are no more likely to mount ill-founded or "long-shot" appeals against large government units than against other kinds of parties, the fact that large government parties had the lowest opponents' appellant success rate provides some support for the thesis that greater litigational resources matter. That business organizations had the second best record on the opponents' success rate measure provides further support. Of course, the assumption stated above could be wrong; perhaps there are more long-shot appeals against state governments (by criminal defendants, for example) or against "deep-pockets" organizations in general.

20 The business proprietors would look even worse as appellants were it not for their success against other business proprietors. We have not removed from the table the numbers and the success rate for parties competing against others like themselves (the cases in the main diagonal) because they are part of the story and because, with the exception of the business proprietors category, the parties' success rate against litigants like themselves never varies by more than $4 \%$ from their success rate overall. 
Table 3. Net Advantage for Different Combinations of Parties, 1870-1970

\begin{tabular}{ll}
\hline \multicolumn{1}{c}{ Combination of Parties } & \multicolumn{1}{c}{ Net Advantage } \\
\hline $\begin{array}{l}\text { Individuals vs. business proprietors } \\
\text { Individuals vs. small town governments } \\
\text { Individuals vs. business organizations } \\
\text { Individuals vs. city and state } \\
\text { governments }\end{array}$ & $\begin{array}{l}\text { Business proprietors by } 2.7 \% \\
\text { Individuals by } 2.2 \%\end{array}$ \\
$\begin{array}{l}\text { Business proprietors vs. small town } \\
\text { governments }\end{array}$ & City and state governments by $8.4 \%$ \\
$\begin{array}{l}\text { Business proprietors vs. business } \\
\text { organizations }\end{array}$ & Small town governments by $13.1 \%$ \\
$\begin{array}{l}\text { Business proprietors vs. city and state } \\
\text { governments }\end{array}$ & Business organizations by $16.3 \%$ \\
$\begin{array}{l}\text { Small town governments vs. business } \\
\text { organizations }\end{array}$ & City and state governments by $20.1 \%$ \\
$\begin{array}{l}\text { Small town governments vs. city and } \\
\text { state governments }\end{array}$ & Business organizations by $10.0 \%$ \\
$\begin{array}{l}\text { Business organizations vs. city and state } \\
\text { governments }\end{array}$ & City and state governments by $23.2 \%$ \\
$\begin{array}{l}\text { Appellant success rate for stronger } \\
\text { parties }\end{array}$ & City and state governments by $6.9 \%$ \\
$\begin{array}{l}\text { Appellant success rate for weaker } \\
\text { parties }\end{array}$ & 533 of 1,268 cases $=42.0 \%$ \\
\begin{tabular}{l} 
Net advantage for stronger parties* \\
\hline
\end{tabular} & 712 of 1,935 cases $=36.8 \%$ \\
\hline
\end{tabular}

*For the 2-by-2 table summarizing the total success rate, Yule's $Y=0.06$, with a two-tail probability of .003 .

the individuals won 34.4 percent of the time. However, when city and state governments were appellants against individual respondents, the former won $\mathbf{4 2 . 9}$ percent of the time, a differential advantage for city and state governments over individuals of 8.5 percent. By following this procedure for all the combinations of litigants, we obtain the measures (unweighted by numbers of cases) presented in Table 3 .

Four observations emerge from this table, although they are sometimes supported by small numbers of cases and small percentage differences. First, not only did city and state governments win more often overall, there also had an advantage vis-à-vis each other type of litigant. Their net advantage over business organizations was 6.9 percent, and 8.4 percent over individuals; it was much larger against business proprietors (20.1\%) and smaller government units (23.2\%). Second, even though, according to our net advantage measure, individuals tended to lose against other types of parties, the margin of disadvantage was small-under 3 percent-save when they were opposed by city and state governments ( $8.4 \%$ ). Third, the fate of business organizations varied more than that of any other category. In terms of our net advantage measure, they won relatively substantially, by a 16.3 percent margin, against business 
proprietors, and by 10 percent against smaller governmental parties. But they did little more than break even against individual appellants $(2.7 \%),{ }^{21}$ and lost by 6.9 percent in litigation against large governments.

Finally, business proprietors tended to do poorly against everyone save individuals, in which case there was no substantial difference. Both large businesses and large governmental parties did substantially better against business proprietorships than against individual litigants, even though we would presume the latter to be weaker than business proprietorships on the average. This could be read to suggest, as the hypothesis that the "have nots" should prevail assumed, that the normative tilt of the law or the biases of supreme court judges led to some favoritism for individuals over businesses.

Nevertheless, the result of this comparison is suggested by the five percent net advantage for the parties presumed to be stronger. Moreover, the individual comparisons in Table 3 consistently show a higher success rate for the presumably stronger party, with the single exception of individuals versus small town governments. At this stage, one would have to conclude that the "haves" did tend to have a certain advantage. 22 We will try to clarify this result by refining our indicators of "have" and "have not" parties and by controlling for area of law, although necessarily with a more restricted number of cases.

\section{The Fate of the Big Interests}

Among all business organizations over the century of litigation covered by our cases, four types might be thought better able to draw on more resources more steadily-railroads, banks, manufacturers, and insurance companies. We are aware

21 As appellants, business organizations won in only $39.1 \%$ of their appeals against individuals. Although business organizations as respondents held individual appellants to a $37.4 \%$ success rate, individuals appealed against business organizations less often than business organizations appealed against individuals; hence, if we look at all cases, disregarding whether business organizations were appellants or respondents, they lost a bare majority (50.7\%) of their cases against individuals.

22 On the other hand, the overall difference is not large. The $5 \%$ margin reflects the fact that individual litigants, presumably the weakest set of parties, figured in over three-fourths of all cases in the sample, and that individuals' margin of loss vis-à-vis other types of parties (except for city and state government units) was less than 3\%. Any large percentage differences in Table 3 favoring the stronger party type involved only a tiny proportion of cases. For example, the $23.2 \%$ margin of victory of larger government parties over smaller government parties is based on only 34 cases drawn from 16 states and spread over a century (representing barely $1 \%$ of the total of the 3,287 cases in the off-diagonal cells). 
that there have been many small and financially weak parties in those lines of business; our assumption is merely that parties in those categories are more likely than "business organizations" in general to have been "haves." Based on that assumption, the success rates of these four kinds of parties in supreme court cases may give us a sharper measure of the hypothesis that parties with greater resources should prevail.

The results, as shown in Table 4, are somewhat ambiguous. On one hand, the larger business interests could not consistently count on using state supreme courts to reverse lower court losses. As appellants, they won only 43.4 percent of their appeals. Only in the instance of railroads appealing against business and government parties did big interests win more than 50 percent of their cases. Moreover, even as respondents the big interests did not totally dominate their opponents, who won 37 percent of their appeals, which was only slightly below average. On the other hand, big interests did achieve a net advantage over individual opponents (by a margin of 5.2\%) and other kinds of businesses (by 13.3\%).

The results vis-à-vis government were mixed. Banks enjoyed an 8.2 percent net advantage over government opponents, but manufacturing firms suffered a net disadvantage (-9.5\%). Railroads did very well as appellants against government parties, winning 61.8 percent, but there were too few government appeals against railroads to compute a net advantage figure, as in the comparison with insurance firms. The mixed results may reflect the weaknesses in our assumption that banks and manufacturing firms were actually stronger litigants, in terms of their command over resources, than government opponents. $^{23}$ In any event, there is little to choose between these major contending parties in regard to outcomes: The differential in favor of the major private interests was a miniscule 1.4 percent.

Next, we compared the record of the big private interests

23 It must be remembered that at least until after World War II, most American banks and manufacturing corporations, and a great many insurance companies, were relatively small organizations. "Fortune 500" names appeared very rarely in our 5,900 case sample. On the other hand, until recently, most state government agencies and attorney generals' offices also were rather small. Hence, our "big interests" types (excluding the railroads) usually were "big" only in a relative sense. This may help explain the smallness of their advantage. Moreover, as has been observed with respect to the United States Solicitor General's office, the government does often pick and choose its cases for appeal, and the relatively low frequency with which governments appealed cases against these major business interests may reflect governments' tendency to offset the larger businesses' financial advantage by being highly selective in deciding which cases to contest or appeal. 
WHEELER, CARTWRIGHT, KAGAN, AND FRIEDMAN

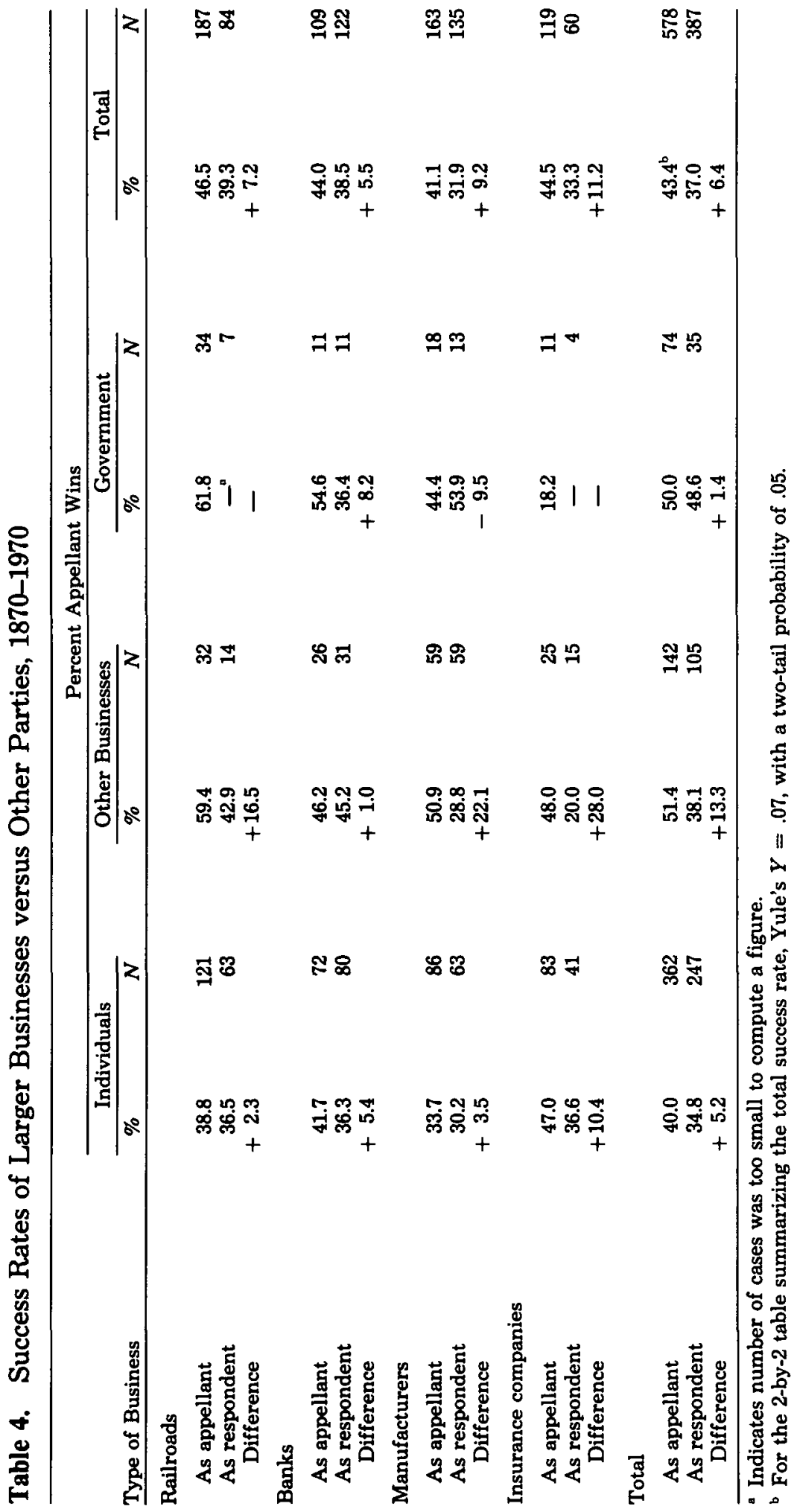


against individual claimants with their record against other business organizations, which were presumably stronger and more organized litigants than individuals. Only insurance companies came out as much as 10 percent ahead when the opposition was individual parties. With the exception of the banks, the major interests fared much better against business parties than against individuals-the railroads had a 16.5 percent advantage over other business opponents, the manufacturers had a 22.1 percent advantage, and the insurance companies had a 28 percent advantage. With this one exception, the results here are about the same as those on our cruder measure of party strength. As the bottom row of Table 4 suggests, the overall net advantage for the big interests is 6.4 percent, only slightly larger than the 5 percent overall result in Table 3 .

\section{The Parties in Specific Legal Arenas}

1. Business versus individuals in private law cases. We now will try to get a little closer to the law itself, first by examining the results in selected areas of private law in which business interests (either proprietors or organizations) often were in litigation against individuals. ${ }^{24}$ Perhaps the basic finding disclosed in Table 5 is how small the differential was between businesses and individual litigants, especially for property and contract cases. The tort cases and the debt collection cases that bulked large on state supreme court dockets produced a somewhat bigger advantage for business parties- -4.3 percent to 4.6 percent. But this effect is offset by the corporation law cases, in which individuals had a large advantage (27.4\%) over business litigants. The net result for private law cases is a $3 \%$ advantage for businesses. Thus, being a "have" party, by these crude measures, produced little or no overall advantage in private law decisions.

2. The government as a party in civil and criminal litigation. We noted in Table 2 that the government, particularly city and state governments, had a better success rate than other litigants. We can now explore in more detail in which situations the government won. Table 6 reports outcomes in cases involving any government party (either state, city, county, or town)

24 Certain party combinations are concentrated in particular areas of law. Governments comprise $96.7 \%$ of the organizational litigants in public and criminal law cases, and businesses comprise $89.3 \%$ of those in private law cases (including property, commercial law, and torts). To avoid confounding party characteristics with areas of the law, we excluded government parties from this analysis of private law disputes. 
Table 5. Success Rates of Businesses ${ }^{a}$ versus Individuals in Private Law Cases

\begin{tabular}{|c|c|c|}
\hline Type of Case & Percent Appellant Wins & $N$ \\
\hline \multicolumn{3}{|l|}{ Property cases } \\
\hline Business appeals against individuals & 34.1 & 91 \\
\hline Individual appeals against businesses & 31.8 & 110 \\
\hline Difference & +2.3 & \\
\hline \multicolumn{3}{|l|}{ Contract cases } \\
\hline Business appeals against individuals & 45.9 & 135 \\
\hline Individual appeals against businesses & 45.0 & 80 \\
\hline Difference & +0.9 & \\
\hline \multicolumn{3}{|l|}{ Debt collection cases } \\
\hline Business appeals against individuals & 38.4 & 151 \\
\hline Individual appeals against businesses & 33.8 & 160 \\
\hline Difference & +4.6 & \\
\hline \multicolumn{3}{|l|}{ Corporation law cases } \\
\hline Business appeals against individuals & 20.0 & 25 \\
\hline Individual appeals against businesses & 47.4 & 38 \\
\hline Difference & -27.4 & \\
\hline \multicolumn{3}{|l|}{ Tort cases } \\
\hline Business appeals against individuals & 40.5 & 338 \\
\hline Business appeals against businesses & 36.2 & 210 \\
\hline \multirow{2}{*}{\multicolumn{3}{|c|}{ Total $^{\mathrm{b}}$}} \\
\hline & & \\
\hline Business appeals against individuals & 39.6 & 740 \\
\hline Individual appeals against businesses & 36.6 & 598 \\
\hline Difference & +3.0 & \\
\hline
\end{tabular}

This category combines business proprietors and business organizations.

b For the 2-by-2 table summarizing the total success rate, Yule's $Y=.03$, with a two-tail probability of .25 .

against individuals or businesses, separately for civil and criminal cases.

The results add texture to what we have reported earlier. The government maintained an advantage in both civil and criminal cases, against both individuals and businesses. Its margin of advantage was larger against businesses: 6.3 percent against businesses versus 4.8 percent against individuals in the civil cases, 21.5 percent versus 6.6 percent in the criminal cases.

The overall governmental advantage in civil cases remained close to the general 5 percent margin for stronger parties, but in criminal cases its net advantage was more than twice that much, 11.6 percent. Here we should emphasize the obvious imbalance in the ratio of government-as-appellant cases to government-as-respondent cases. The relatively small number of cases in which the government appeals on matters of criminal law may be rather special and idiosyncratic. Since criminal appeals have been one of the major growth areas in state supreme court litigation (Kagan et al., 1977), and since criminal defendants' appeals are often (at least in recent years) financed by the state, making it cost nothing to appeal on weak legal grounds, it is surprising that the differential is not even 
Table 6. Success Rates of Governments versus Individuals and Businesses in Civil and Criminal Cases

\begin{tabular}{|c|c|c|}
\hline Type of Case & Percent Appeliant Wins & $N$ \\
\hline \multicolumn{3}{|l|}{ Civil Cases } \\
\hline Government appeals against individuals & 41.2 & 177 \\
\hline Individual appeals against governments & 36.4 & 286 \\
\hline Difference & +4.8 & \\
\hline Government appeals against businesses & 48.5 & 132 \\
\hline Business appeals against governments & 42.2 & 223 \\
\hline Difference & +6.3 & \\
\hline Total: Government as appellant & 44.3 & 309 \\
\hline Government as respondent & 38.9 & 509 \\
\hline Difference & +5.4 & \\
\hline \multicolumn{3}{|l|}{ Criminal cases } \\
\hline Government appeals against individuals & 43.3 & 30 \\
\hline Individual appeals against governments & 36.7 & 652 \\
\hline Difference & +6.6 & \\
\hline Government appeals against businesses & 63.6 & 11 \\
\hline Business appeals against governments & 42.1 & 76 \\
\hline Difference & +21.5 & \\
\hline Total: Government as appellant & 48.8 & 41 \\
\hline Government as respondent & 37.2 & 728 \\
\hline Difference & +11.6 & \\
\hline Overall Government as appellant & 44.9 & 350 \\
\hline Government as respondent & 37.9 & 1,237 \\
\hline Difference* & +7.0 & \\
\hline
\end{tabular}

*For the 2-by-2 table summarizing the overall government advantage, Yule's $Y=$ .07 , with a two-tail probability of .02 .

larger. The success rate of individual appellants against the government in criminal cases (36.7\%) was only a little bit below the 40 percent success rate for all appellants in all kinds of cases, and was as high as the success rate for individuals appealing against the government in civil disputes.

The overall result of Table $6-a$ percent net advantage for the government-lends further confirmation to our basic finding, for the stronger party did tend to come out ahead, but again not by any striking margins.

\section{E. The Parties in Specific Legal Relationships}

For a subset of all our cases-about a fifth of the more than five thousand cases with which we started-we can examine certain prototypical role relations: in property law, landlords versus tenants; in contract cases, creditors versus debtors; in employment, the employer versus the employee; and in workplace accidents, the employer versus the worker-victim. Here again there may be individual reversals of one pattern (e.g., a wealthy tenant dealing with a poor landlord), but on balance we feel fairly safe in designating landlords, creditors, and employers as the "haves."

When the parties' fates can be seen in such specific legal 
relationships, as shown in Table 7, a consistent and more dramatic pattern emerges. Landlords, creditors, and employers consistently had substantially more success than tenants, debtors, and employees. The employers represented in workplace accident cases also did better than injured workers. ${ }^{25}$ The stronger parties' net advantage of 9.3 percent is larger than any of our other overall results, in which "have" and "have not" identities were less sharply isolated.

\section{THE DIFFERENCES OVER TIME}

To see if the overall conclusions are altered by changes that occurred over time, we divided our twenty-one sampling points into three periods: $1870-1900,1905-35$, and 1940-70. The effect of this periodization on the balance of advantage in state supreme courts is somewhat different for private and public areas of law. In private litigation, business parties did a little better than their individual opponents in all three time periods, but the differences were very small. ${ }^{26}$

Torts, collection, and property cases gave more advantage to "have" parties in the nineteenth century. After World War II, the various slight differences pointed if anything in favor of the "have nots." Contract and other commercial cases tended to go the other way, however, with greater advantage to the "haves" in recent times.

Because of these divergent trends, we hesitated to pool our cases to establish a somewhat broader measure of changes over time. But we did construct one index that captures, as best our imperfect data can, the effect of disparities in private party strength on outcomes and changes in that effect from 1870 to 1970. All litigants are scored on a 1-5 continuum, getting a 1,2 , or 3 depending on whether they are an individual, business proprietorship, or business organization, an additional point for being a "major interest" (bank, insurance company, railroad, or

25 The workplace accident cases combine the traditional tort cases that arose prior to the establishment of the worker's compensation system and cases processed through that system. The overall $7.6 \%$ advantage conceals an interesting difference between the two categories. In the tort claim cases, employer-appellants had a $12.7 \%$ advantage, and in the worker's compensation cases only a $2.4 \%$ advantage. In some ways, this is not a surprising result. The old rules were biased against the worker, and the new system was supposed to restore the balance.

26 On the average, the "big interests" identified in Table 4 did somewhat better in the later time period than in the earlier, although their fates were not uniform: Manufacturing companies and insurance companies fared better in more recent decades, banks enjoyed their major advantage during the 1905-35 period, and the railroads were most successful before the turn of the century. But these differences are necessarily based on very small numbers, and none, taken individually, is statistically significant. 


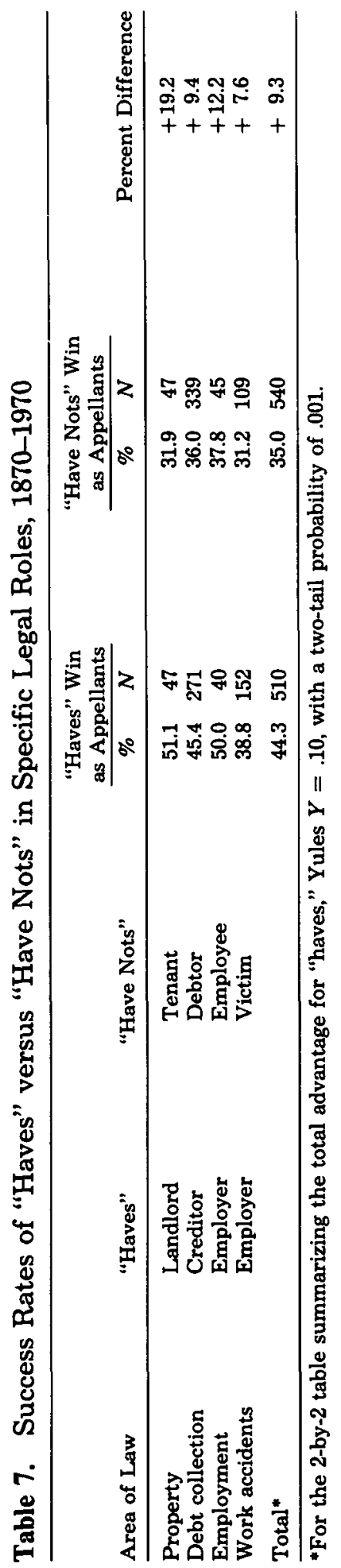


manufacturing firm) and another for being in one of our more specific "have" categories (creditor, employer, or landlord). For example, a maximum disparity score would be indicated when a manufacturing company was a creditor against an individual debtor; a minimum disparity score would hold for two individual litigants (or even two business organizations), neither of whom was one of our "big interests" but one of whom was a creditor and the other a debtor. The results of this analysis are portrayed in Table 8.

Several findings are apparent from the table. First, to reinforce a point made earlier, extreme disparities in party strength are not often found at the level of state supreme court litigation. Fewer than 15 percent of cases in our sample pitted opponents in the highest disparity category. Second, there was by no means a uniform and steady relation between the extent of disparity and party outcomes. Taking the 1870-1970 period as a whole, at the lowest levels of disparity the advantage to the stronger parties was under 5 percent, but was slightly smaller in the middle level of disparity compared to the lowest. It is only in the highest disparity category that one finds an effect substantially larger than our general "five percent" figure, and then the rise is only up to 8 percent. Third, although the evidence is hardly overwhelming or uniform, it seems that the effect of disparity has lessened over time. That is true overall, with a decline from a 6.3 percent advantage for the stronger parties during the late nineteenth century to only 1.8 percent in the post-World War II period. This is more apparent when there is a high degree of disparity between parties; the 18 percent difference during the latter nineteenth century declines to 3.2 percent in the mid-twentieth. All this suggests, that for the area of private law, relative resources do make some difference, although it is a difference that apparently has been shrinking in the most recent decades. ${ }^{27}$

A quite different finding characterizes the public law arena. The overall probability of a government party winning in a criminal appeal was 47 percent in the late nineteenth century, 66 percent in the early twentieth, and 68 percent in the 1940-70 period. A similar trend is evident in civil cases in which the government is a party: the government won fewer

27 It is possible, of course, that this shrinking applies only to state supreme courts and not to intermediate appellate courts or, of course, to trial courts. The trend may also be the product of change that occurred only in some state supreme courts, and it may not hold for specific areas of law or periods of time. 


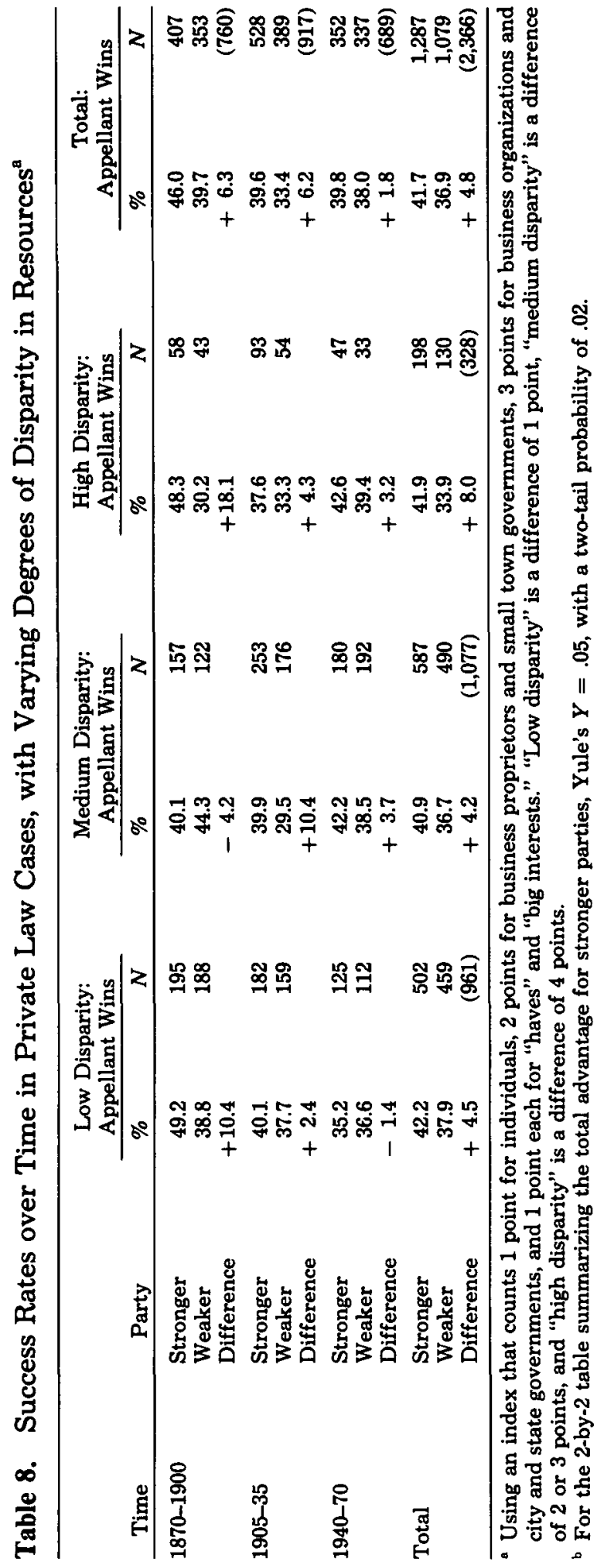


than it lost (49\%) in the late nineteenth century, but increased its rate of success markedly to 64 percent during the early part of the twentieth century and to 67 percent in the most recent decades. Thus in the public law arena there has been a very clear trend toward greater advantages for the government party over time. This coincides with an increase in the proportion of all state appellant court cases that fall in the public law arena, especially criminal appeals (Kagan et al., 1977).

But these clear empirical findings do not permit any similarly clear and unambiguous interpretation. Why, for example, did the government do better in criminal appeals in recent years than in the late nineteenth century? One might speculate that pro-defendant criminal case rulings during the Warren Court era, including rights to free counsel, encouraged more appeals based on procedural violations that supreme court judges found "harmless" (Davies, 1982). More fundamental, however, are two blunt facts. First, the course of the government's success rate over time is very similar in both civil and criminal cases, suggesting that something about government itself has been at work, such as greater professionalization of its administrative and legal operations. Second, the biggest increase in government victories in both civil and criminal litigation occurred not from World War II into the era of the Warren Court but in the late nineteenth and earlier twentieth centuries. Again, this coincides with a period of professionalization and reform in state and city governments and the advent of the "harmless error" rule. ${ }^{28}$

Taken together, the historical trends in private and public law do lend some clarity to what we learned earlier. The private law arena offers a slight advantage to the relatively stronger parties, although this advantage has diminished over time. The public law arena, on the other hand, has seen government parties win far more often than their adversaries, with great gains in the early twentieth century and more modest gains in the most recent period.

28 The aggregate trends undoubtedly mask some interstate variation. Using our data, Meeker (1984) found relatively little cross-regional variation in criminal appellants' success rates, except in our sample of supreme courts in the Northeast (Maine, Rhode Island, and New Jersey). In those courts, criminal defendants' odds on appeal were lower than in other regions in the 1870-1925 period but were better than in other regions in the 1960-70 period. In an earlier article (Kagan et al., 1978), we noted that in 1940-70 criminal appellants did better, on the average, in supreme courts with case-selecting discretion. In Michigan, California, and West Virginia, the reversal rate in criminal cases in 1940-70 exceeded $50 \%$, an increase of more than $25 \%$ from the 1905-35 period. 


\section{THE EFFECT OF LEGAL COUNSEL}

In theory, stronger parties might tend to prevail because they might be able to mobilize more potent legal counsel. On this point, we have at least a modicum of data. In coding supreme court cases, we distinguished among pro se parties (a tiny faction), parties with lawyers in solo practice, and those represented by a partnership or firm. The latter might not have an advantage in any particular case, but over the run of cases, clients represented by firms, which are likely to have more specialization and resources, might be expected to have an edge. Although data on type of counsel in most supreme court opinions are far from ideal, ${ }^{29}$ they do provide at least a starting point for further analysis..$^{30}$

The most relevant data appear in Table 9 , where we began by separating the private law cases into four categories based on whether the attorneys represented appellants or respondents, and were solo practitioners or members of a partnership or firm. We then further divided the cases, using the disparity of party strength index reported in Table 8, according to whether the stronger or the weaker party appealed (setting aside for the moment differences in the degree of disparity between them).

Table 9 shows that there is an apparent 7 percent advantage for firm attorneys: when they appealed against a party

29 For research purposes, the identification of lawyers in supreme court opinions leaves much to be desired. It is not always clear whether an attorney mentioned in the head note is representing the client on his own or whether that attorney is a member of a firm. The coding was based on whatever could be gleaned from the materials in the head note, but there may be more than the usual amount of error in those materials.

30 Studies attempting to relate differences in quality of contemporary appellate lawyering to size of firm have produced mixed results. A study of appellate advocacy in United States circuit courts compared judges' views of the quality of lawyers' presentations with several objective characteristics, such as the size of the lawyer's office and the lawyer's age, years of experience in law and appellate advocacy, and quality of law school. No statistically significant associations were found (Partridge and Bermant, 1978: 187-208). Marvell (1978: 39), in his study of appellate litigation in a large-state supreme court, found no significant relationship between size of firm and winning or losing; nor were lawyers with higher Martindale-Hubbell ratings (compiled by fellow lawyers) or more experience more likely to win. However, Marvell did find that attorneys who had gone to top law schools, when opposed by attorneys who had not, won almost twice as often as they lost. In addition, when he ventured his own qualitative assessments of briefs and arguments in 109 appeals, he found that while in nearly $40 \%$ of cases "opposing counsel seemed to do about the same caliber of work" (ibid., p. 40), in other cases, (a) "law firm lawyers seemed to do considerably better work than solo practitioners" (ibid., p. 68 , and (b) attorneys who in Marvell's opinion "did a better job won almost three-fourths of the time. Moreover, the better almost always won the few cases in which the difference between presentations seemed very large" (ibid., p. 40). 


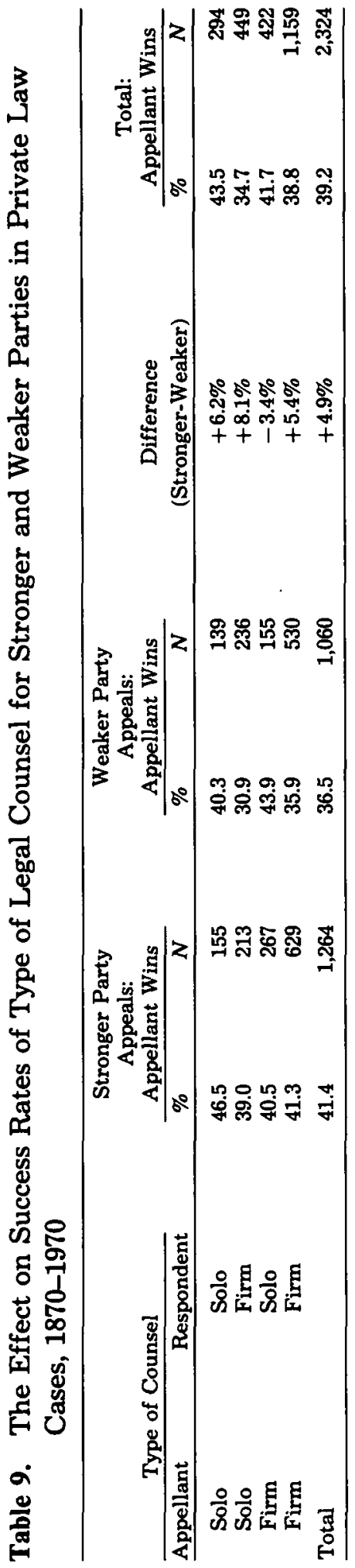


represented by a solo practitioner, they won 41.7 percent of the time, in contrast to 34.7 percent for a solo practitioner appealing against a partnership or firm. But this overall advantage is arrived at in very different ways for the stronger and weaker parties:

1. When the stronger party represented by a solo practitioner appealed against a party represented by a firm, the stronger party won 39.0 percent of the time. A weaker party in the same situation won only 30.9 percent of the time, with a resulting 8.1 percent advantage for the stronger party.

2. When the stronger party was represented by a partnership or firm that appealed against a weaker party represented by a solo practitioner, its win ratio hardly changed-from 39.0 percent to 40.5 percent.

3. When a weaker appellant was represented by a firm and opposed by a solo practitioner, its success rate rose 13 percent to 43.9 percent.

4. Conversely, stronger parties did better as respondents when they were represented by firms rather than by solo practitioners. ${ }^{31}$

Usually, therefore, partnership or firm representation seems to have affected outcomes. ${ }^{32}$

31 Stronger party respondents held weaker party appellants with solo lawyers to a $40.3 \%$ success rate when the stronger party also had a solo lawyer but to a mere $30.9 \%$ when the stronger party was represented by a firm. When weaker appellants had firm lawyers, stronger party respondents held them to a $43.9 \%$ success rate (which was quite high) when the stronger parties were represented by solo lawyers, but that figure was reduced to $35.9 \%$ when the stronger parties also were represented by firms.

32 Although we are not here concentrating on differences over time, two time-related effects should be noted. First, as anyone would suppose, the probability that both parties are represented by solo practitioners declined over our three time periods from $18.9 \%$ to $11.6 \%$ to $7.8 \%$, with partnership or firm representation of both parties rising from $41.3 \%$ to exactly $50 \%$ to $56.0 \%$. Perhaps the surprising finding is that even in the post-World War II era, a large minority of litigants are still represented by solo practitioners. This may be partly due to the aforementioned data problem-some lawyers representing firms may have been misclassified as solo practitioners. But it may also be the case that our expectations are overly influenced by the prominence of the big case and the big city jurisdiction. Our litigants often came from small communities in small states, where many solo practitioners are still alive and well. There are also large numbers of criminal, tort, worker's compensation, domestic relations, and tax cases, fields in which solo practitioners still thrive, even in the cities. See Heinz and Lauman, 1982.

Second, solo practitioners were not doing as well in state supreme courts in $1940-70$ as at the turn of the century. In the $1870-1900$ period, the success rates for solo appellants in private law cases were actually higher than for partnerships or firms $-43.8 \%$ to $39.2 \%$. But that margin more than reversed in 1905-40; $32.2 \%$ for solo appellants, $41.6 \%$ for firms. They were more equal in the $1940-70$ period- $38.7 \%$ to $41.9 \%$. If we included all the government cases and treated state attorney generals' offices as firms, the differential in favor of firm representation would be greater, for the government as litigator has been more successful in recent times. 
To see more precisely how law firm representation affected outcomes, Table 10 applies the disparity index as developed in Table 8 to the comparison of cases with different types of counsel seen in Table 9. This enables us to contrast outcomes when there is the maximum ostensible difference in party strength, the closest we can come to approximating real "have" versus "have not" parties.

Consider first the results when strength disparities between the parties were high. Here the configuration of lawyers seems to make little difference. As appellants, the stronger parties actually did worse (winning $38.1 \%$ ) when they were represented by firms and their weaker opponents had solo lawyers than when the opposite lawyer match-up occurred (52.6\%), although the small number of cases in the latter category leads us to discount its significance. Similarly, weaker parties as appellants did just about as poorly (winning only 27.8\%) against much stronger parties when the weaker had a firm lawyer and the stronger party did not as when they had the ostensibly less favorable lawyer configuration (25\%).

On the other hand, when disparities in party strength were low or medium, favorable lawyer configurations seemed to help the weaker party greatly:

1. When medium disparity exists, weaker appellants with a lawyer disadvantage (they had a solo practitioner, the respondent had a firm) won only 29.1 percent of their appeals, but when they had the apparent advantage in lawyer type, they won 47.8 percent.

2. A similar reversal in weaker appellants' fate, depending on whether they had an advantage or disadvantage in lawyer type, occurred in the low disparity category.

3. In terms of our net advantage measures, when appellants were represented by law firms and respondents by solo practitioners, weaker parties actually secured an advantage of 8.3 percent and 3 percent, respectively, over opponents with low or moderate strength advantage. ${ }^{33}$

To what extent did imbalances in legal representation account for the overall advantage in outcomes achieved by stronger parties? As might be expected, stronger parties were more often represented by firms against weaker parties represented by solo lawyers; Table 9 shows that this occurred in 503

33 For low and medium levels of disparity combined, the net advantage of firm representation for weaker appellants was $14.3 \%$, calculated as follows: Percent appellant wins for low and medium combined $=46.0 \%(137) ; 31.7 \%$ (208); Difference $=14.3 \%$. 


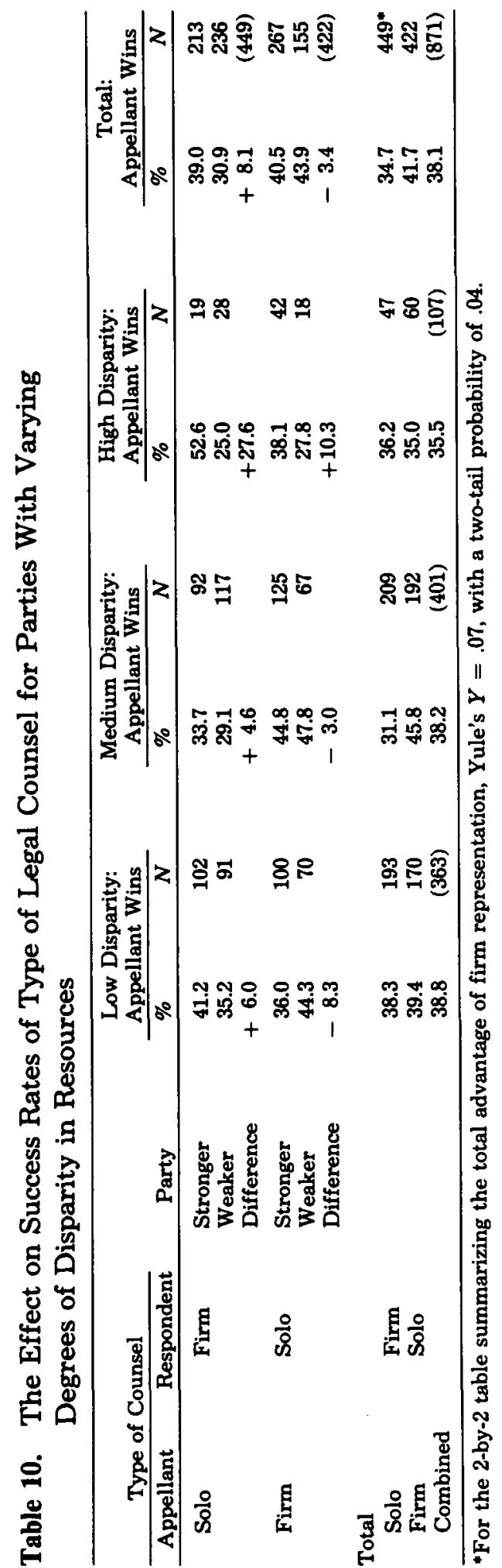


of the 2,324 private law cases for which these calculations could be made. However, in 368 cases the weaker party was on the ostensibly favorable end of the mismatch, that is, with their firm lawyers facing a stronger party's solo practitioner. The stronger parties' net advantage in type of lawyer, therefore, existed in only 135 , or 5.8 percent, of the private law cases. ${ }^{34}$

On the other hand, the data in Table 9 suggest that the approximately 5 percent aggregate advantage enjoyed by stronger parties in private law cases was not due simply to disparities in type of lawyer. When we compare the success rates of stronger and weaker parties while holding constant type of lawyer configurations, stronger parties retain net advantages of 6.2 percent when both parties had solo lawyers, 5.4 percent when both had firms, and 8.1 percent when appellant had a solo lawyer and respondent had a firm. In only one configuration-when appellant had a law firm and respondent had a solo practitioner-did the stronger parties' advantage disappear. Similarly, as Table 10 indicates, stronger parties retained a large net advantage regardless of lawyer configuration. On balance, therefore, the stronger parties' advantage does not appear to be due in any major degree to imbalances in type of lawyer, or at least to those revealed by our simple solo-versus-firm indicator. Thus these results, although consistent with others presented in this paper, leave much to be explained. ${ }^{35}$

\section{SUMMARY AND CONCLUSION}

Our findings may be summarized as follows:

1. Success rates of appellants versus respondents. In the 1870 1970 period, the greatest advantage among state supreme court litigants went to those who won in lower courts. They enjoyed

34 Lawyer mismatches in favor of the stronger party occurred most often when the party strength disparities were greatest. Of the attorney mismatches in Table 10's low disparity category, 191 favored stronger parties and 172 favored weaker parties. In the high disparity category, the stronger parties enjoyed 70 favorable mismatches and the weaker parties only 37 .

35 To summarize the overall relationships in Tables 8-10, we have conducted a log-linear analysis showing the effects of resource disparities and type of legal counsel on party outcomes. Several points are worth noting. As a general rule, stronger parties do tend to come out ahead, but the explanatory power of party strength, taken by itself or mediated by other variables, appears to be fairly low. None of the models expressing various interactions among time, party strength, resource disparity and type of legal counsel fits the data, and even the best fitting models leave approximately $80 \%$ of the variation in outcomes unexplained (with G2 probabilities less than .01). Thus while party strength seems to have a consistent impact on appellate outcomes, its force, based on the rough surrogate measures available in our study, appears to take us only a modest distance in explaining affirming and reversing in state supreme courts. 
a roughly 20 percent advantage (60\% to $40 \%$ ) over appellants in their success rates. All broad categories of parties, including the presumably stronger ones such as business organizations and larger government units, lost as appellants more often then they won. As respondents, all classes of parties, including presumably weaker ones such as individuals and small proprietorships, won more often than they lost.

2. Overall success rate, as appellant and respondent, combined. Individuals, business organizations, and business proprietors appeared about as often in the favored respondent role as in the disfavored appellant posture. Hence the overall win-loss ratio, for both stronger and weaker categories of private parties, was close to $50: 50 .{ }^{36}$

State and city governments, partly because they were less frequently in the "underdog" appellant role, won in a clear majority-60.2 percent-of their supreme court appearances. But smaller government parties, despite appearing more often as respondents, managed only a 51.5 percent overall success rate, more like the private parties.

In sum, no broad type of party, either "have" or "have not," consistently won or lost, with the exception of state and large city governments. Further, even their 60 percent to 40 percent margin of victory reflected the fact they were appellants in only 29.1 percent of their supreme court cases.

3. The competition between classes of parties: Who had the advantage? In view of the supreme courts' general bias against appellants, most of our analysis was devoted to discovering which party was best able to exploit the respondent's general advantage. We asked, for example, whether individual appellants did better against business and government parties than business and government appellants did against individual respondents. We found that parties with greater resources-relatively speaking, the "haves"- -generally fared better than those with fewer resources. In match-ups between stronger and weaker parties, the stronger consistently and on a variety of different measures won an advantage averaging 5 percent.

State and city governments had the strongest record, with an average net advantage of 11.8 percent over all categories of parties in both civil and criminal cases. Business organizations tended to be overmatched by larger governmental parties, against whom they suffered a net disadvantage of 6.9 percent.

36 See Table 2. 
But businesses enjoyed a 10 percent margin over smaller government units, and one subset of business firms, railroads and banks, even won more often than they lost when acting as appellants against government opponents. Business organizations did not win very often over individuals, the presumably weakest parties, ekeing out a net advantage of only 1.8 percent. Even an ostensibly powerful set of businesses-railroads, banks, manufacturers, and insurance companies-won only a net 5.2 percent advantage over individuals.

However, when we restricted our sample to specific types of cases with clearly defined role relationships-such as employers against employees, creditors against debtors, landlords against tenants-the stronger party had a significant net advantage, ranging from 7.6 percent to 19.2 percent. This suggests that had we been able to measure more sharply which parties were "haves" and which were "have nots," the overall disparity would have been greater than those revealed by our analysis of business organizations in general.

In terms of changes over time, the relative advantage of stronger parties in private law cases was smaller in 1940-70 than at the turn of the century. But the advantage held by government parties in both civil and criminal cases has grown since 1900, primarily between 1905 and 1935 .

Finally, although large parties generally did better against small ones, there was an interesting subtheme to which we will allude later: larger government and business parties had a greater margin of success against smaller organizations, especially small businesses, than against individuals.

\section{A. Why Did the "Haves" Come Out Ahead?}

Earlier we mentioned three reasons why stronger parties might be expected to win more often: (1) the philosophy underlying the law favors them, (2) the judges favor them, and (3) they have better litigation skills. Our data do not provide a direct test of any of these hypotheses, but they do contain circumstantial evidence that provides some speculative answers.

One might argue, for example, that the clear net advantage achieved by larger government parties stems from a strain in the law toward upholding government authority in close cases or from a similar bias on the part of supreme court judges. But the fate of small government parties seems to undercut that argument, for unlike state and big city governments, small cities and county sheriffs failed to achieve a net advantage vis-à-vis individuals and business organizations. As respondents, they 
won only 55.9 percent of their cases, compared to 63.6 percent for large governments and 60 percent for individuals. If the spirit of the law favored government interests, it would not have done so only for big governments. ${ }^{37}$ It likewise seems unlikely that state supreme court judges, drawn in large measure from small town legal practices and county courthouses (Kagan et al., 1984), would have had a stronger attitudinal bias toward state and big city governments than toward small local government parties. Small governments' poor performance compared to larger government parties, as well as the large net advantage (23.2\%) achieved by the latter against the former, suggests that greater legal sophistication and litigational capabilities were the primary source of the larger units' advantage.

A similar interpretation applies to the net advantage won by larger business firms against individuals and small government parties. If that advantage had been due to a general tilt in the normative structure of the law toward business interest, or to probusiness judicial attitudes, small businesses would presumably have achieved a similar advantage. Statutes and common law precedents, even if they favor business interests, rarely distinguish among firms by size. In addition, state supreme court judges, who come far more often from local politics and legal practice than from big city corporate law firms (ibid.), would likely not have been more strongly biased toward large companies than toward small businesses. Yet small businesses did far worse than larger business organizations against every type of party, ${ }^{38}$ and they sustained a 16.3 percent net disadvantage against the larger business entities. This suggests that the net advantage won by business organizations flowed primarily from their litigational capabilities.

We were able to measure one aspect of litigational capabilities, and this points to similar findings. Legal resources, as indicated by representation by a partnership or law firm rather than a solo practitioner, appeared to affect outcomes. Except in the comparatively few cases of great difference in party strength, the weaker appellant, when represented by a law firm against the stronger respondent's solo practitioner, did far better than when the reverse occurred. ${ }^{39}$ Thus some of the

37 It could be argued that larger governments were better able to meet legal requirements applicable to government and that during litigation rigorous applications of the law thus favored them. We would not call this, if it occurred, a normative tilt of the law toward the larger units but a reflection of the greater legal competence of parties with more resources and legal experience.

38 See Table 3.

39 See Tables 9 and 10 and text above. 
stronger parties' net advantage seems to have come from their better legal representation. But the advantage cannot be completely attributed to this factor, for when both stronger and weaker parties had the same type of lawyer the stronger retained a net advantage. We cannot know if the stronger party's solo practitioner was, on the average, more experienced and skillful or spent more time on the case than the weaker party's solo practitioner.

The greater resources of stronger parties presumably confer advantages beyond hiring better lawyers on appeal. Larger organizations may be more experienced and thus better able to conform their behavior to the letter of the law or to build a better trial court record, matters on which we have no evidence. Experience and wealth also imply the capacity to be more selective in deciding which cases to appeal or defend when the lower court loser appeals. As noted earlier, state and city governments, which were apparently selective about appealing, had the highest appellant success rate, 10 percentage points above those for individuals and proprietors, who typically were less experienced, "one-shot" litigants. ${ }^{40}$ Another indicator of the importance of selectivity is that in criminal cases, business defendants succeeded in 42.1 percent of their appeals, compared to 36.7 percent for individual defendants, who, faced with the possibility of incarceration, presumably would be more likely to take "long-shot" appeals. ${ }^{41}$

In view of the seeming importance of legal sophistication in choosing when and how to litigate, one of the most intriguing results is the comparatively strong showing of individual parties. Their net disadvantage against stronger parties was less than 5 percent or 6 percent on most measures. One reason for this may be that they were able to hire reasonably good lawyers, whose skill and experience came close to offsetting their

40 For political and institutional reasons, government parties may be more risk averse in litigation than individuals and businesses. For example, if prosecutors are judged by their rate of successful prosecutions, they may strive to litigate only those cases they are sure they can win, settling or dropping those that would be prosecuted under a different cost-benefit strategy. Some regulatory agencies have been found to concentrate on prosecuting "easy winners" rather than more important but more difficult cases (see Posner, 1972). The same calculus may have been applied by understaffed state attorney generals' offices in deciding whether to accept or contest appeals referred by other agencies. See, by analogy Rabin, 1972; Olson, 1984.

41 Was this disparity due to legal or judicial favoritism toward business criminal defendants? Our data suggest not, for when the government appealed in criminal cases, it did better against business defendants than against individual defendants (see Table 6). This implies that the reason business did better than individuals as appellants in criminal cases had more to do with their greater selectivity than with judicial sympathy for them. 
clients' inexperience and lack of resources. From this perspective, the relatively small net disadvantage of weaker parties reflects precisely the extent to which their lawyers were less experienced or prepared than those of stronger, better-paying parties.

Some normative factors may also have contributed to this result. Why, for example, did individuals so often do better against powerful parties than business proprietors, who presumably would have done about as well as individuals in choosing and paying lawyers? Could it be that individuals were more likely to attract judicial sympathy? Perhaps, as the hypothesis that the "have nots" should prevail states, there often was a "pro-underdog" bias in the normative system or in the minds of supreme court judges that tended to offset, at least in part, individual parties' relative disadvantage in litigational experience and capacity. ${ }^{42}$

\section{B. Was the Advantage Enjoyed by the "Haves" Really Significant?}

The likelihood that patterns of winning and losing in state supreme courts were due to a number of cross-cutting factors, with advantages for one type of party at least partly offsetting advantages of others, raises another question: Was the margin of victory won by the "haves" significant enough to try to explain at all, or should these results be viewed as more consistent with the hypotheses that no group or category has a consistent advantage? The answer depends on the measures one concentrates on and the expectations one holds.

From one perspective, the stronger parties' advantage seems insignificant. Putting aside the tendency of respondents to win and looking instead at the combined success rates, individuals, small businesses, small governments, and business or-

42 It is interesting, from this standpoint, that while business parties, which were presumably more selective in choosing their cases, won $42.2 \%$ of their civil appeals against government as compared to $36.4 \%$ for individual appellants, this pattern was reversed when the government appealed civil cases. In such instances government won only $41.2 \%$ of their cases against individuals as compared to $48.5 \%$ against business (see Table 6). Similarly, when business organizations appealed, they did worse against individuals than against proprietors or government parties (see Table 2). This pattern could suggest that supreme court judges had some tendency to favor individuals-as a result of either their pro-"underdog" attitude or their interpretation of the law or both-although that bias was not strong or uniform enough to totally offset individuals' relative lack of resources and legal sophistication in selecting, preparing, and defending appeals. The general decline in stronger parties' net advantage in twentieth-century private law cases (see Table 8), in an era in which the law and judicial attitudes have shifted toward more egalitarian positions, also points in this direction. 
ganizations all won in state supreme courts just about as often as they lost. Taking lower court outcomes as the baseline, the courts did not systematically redistribute resources toward any of these interests. The apparent exception was the courts' tendency to support the position of state and big city governments about 60 percent of the time. But even that reflects larger governments' propensity to appear much more often as respondents; as appellants attempting to reverse lower court decisions, larger governments lost about 52 percent of their cases.

Proponents of the "null hypothesis" would grant that stronger parties managed to wrest an advantage over their weaker opponents of 3 percent here, 10 percent there, and 5 percent on average, but that margin, they would argue, is very small in view of the enormous real difference in resources between small and big parties and thus indicates that the system operated rather neutrally. To sustain the thesis that party characteristics significantly affected results, much larger disparities would have to be produced.

The rebuttal would be that the net advantage for the stronger parties was a significant result because it was so consistent, reappearing for subsamples of different pairs of party types and different types of cases, business firms and commercial role relationships, and lawyers. Stronger parties may not have won by a large percentage on some measures, but they did win. Had the supreme courts consistently been uninfluenced by party characteristics or had the parties been evenly matched, this pattern simply would not have recurred. In fact, the narrowness of the stronger parties' net advantage for some pairings probably reflects the failure of the court opinions to yield clear data on party strength. In our data, the more sharply party disparity can be delineated, the larger the net advantage of the stronger parties, and some of those advantages are really substantial. Thus the consistent advantage to the "haves" in our results probably understates their true advantage.

In assessing these perspectives, one's original expectations matter a great deal. For those who start with the assumption, based on materialist theories of the legal process, that stronger interests dominate the judicial process and hence should win by large margins, the results are decidedly disappointing. "Little guys" could and did receive justice in the state supreme courts, at least in the sense of winning almost half of the time. But if one starts out with an idealist image of the court system as providing a law-guided, neutral forum for reasonably well represented adversaries, our discovery of a consistent margin of vic- 
tory for stronger parties is hard to explain or dismiss, and represents a significant blow to that concept.

We cannot, of course, conclusively resolve these differences in interpretation. This is partly because the measures of stronger and weaker parties extractable from the cases were unavoidably rather general.43 More fundamentally, data on case outcomes alone cannot tell us what is fair or unfair. We feel, however, that by offering an overview of the actual results in a large sample of cases, we have provided a solid basis for narrowing the discussion.

\section{REFERENCES}

BLACK, Donald J. (1976) The Behavior of Law. New York: Academic Press. CANON, Bradley, and Dean JAROS (1969) "State Supreme Courts-Some Comparative Data," 42 State Government 260.

CARTWRIGHT, Bliss (1975) "Conclusion: Disputes and Reported Cases," 9 Law \& Society Review 369.

CHIN, Audrey, and Mark PETERSON (1985) Deep Pockets, Empty Pockets: Who Wins in Cook County Jury Trials. Santa Monica, CA: Rand Corporation.

DAVIES, Thomas Y. (1982) "Affirmed: A Study of Criminal Appeals and Decision-Making Norms in a California Court of Appeal," 1982 American Bar Foundation Research Journal 543.

DWORKIN, Ronald (1967) "The Model of Rules," 35 University of Chicago Law Review 14.

FRIEDMAN, Lawrence M. (1985) Total Justice. New York: Russell Sage Foundation.

(1985) A History of American Law. New York: Simon \& Schuster.

FRIEDMAN, Lawrence M., Robert A. KAGAN, Bliss CARTWRIGHT, and Stanton WHEELER (1981) "State Supreme Courts: A Century of Style and Citation," 33 Stanford Law Review 773.

FRIEDMAN, Lawrence M., and Robert V. PERCIVAL (1981) The Roots of Justice: Crime and Punishment in Alameda County, California, 1870-1910. Chapel Hill: University of North Carolina Press.

GALANTER, Marc (1975) "Afterward: Explaining Litigation," 9 Law \& Society Review 347.

(1974) "Why the 'Haves' Come Out Ahead: Speculations on the Limits of Legal Change," 9 Law \& Society Review 95.

HARRIS, Peter (1985a) "Difficult Cases and the Display of Authority," 1 Journal of Law, Economics and Organizations 209.

(1985b) "Ecology and Culture in the Communication of Precedent among State Supreme Courts, 1870-1970," 19 Law \& Society Review 449.

HEINZ, John P., and Edward O. LAUMAN (1982) Chicago Lawyers: The Social Structure of the Bar. New York: Russell Sage Foundation.

HOFFERBERT, Richard (1968), "Socioeconomic Dimensions of the American States: 1890-1960," 12 Midwest Journal of Political Science 401.

43 Those weak parties, it could be argued, who have persisted through the lower court litigation and on through the state supreme court, are those whose weakness was never organic to their condition or who have transcended, in one way or another, the gross categories into which we necessarily placed them. Yet this position is consistent with either the view that our data understates the disadvantage of truly weaker parties or the view that the appellate legal system is so structured to be very close to neutral, since whatever their origin, there are few truly weak parties in state supreme courts. 
HOWARD, J. Woodford (1981) Courts of Appeals in the Federal Judicial System: A Study of the Second, Fifth and District of Columbia Circuits. Princeton: Princeton University Press.

KAGAN, Robert A. (1984) "The Routinization of Debt Collection: An Essay on Social Change and Conflict in the Courts," 18 Law \& Society Review 323.

(1978) Regulatory Justice: Implementing a Wage-Price Freeze. New York: Russell Sage Foundation.

KAGAN, Robert A., Bliss CARTWRIGHT, Lawrence M. FRIEDMAN, and Stanton WHEELER (1978) "The Evolution of State Supreme Courts," 76 Michigan Law Review 961.

(1977) "The Business of State Supreme Courts, 1870-1970," 30 Stanford Law Review 121.

KAGAN, Robert A., Bobby D. INFELISE, and Robert R. DETLEFSEN (1984) “American State Supreme Court Justices, 1900-1970," 1984 American Bar Foundation Research Journal 371.

LEFF, Arthur A. (1970) "Injury, Ignorance and Spite-The Dynamics of Coercive Collection," 80 Yale Law Journal 1.

MARVELL, Thomas (1978) Appellate Courts and Lawyers: Information-Gathering in the Adversary System. Westport, CT: Greenwood Press.

MEEKER, James W. (1984) "Criminal Appeals over the Last 100 Years," 22 Criminology 551.

OLSON, Susan M. (1984) "Challenges to the Gatekeeper: The Debate over Federal Litigating Authority," 1984 Judiciature 71.

PARTRIDGE, A., and G. BERMANT (1978), The Quality of Advocacy in the Federal Courts. Washington, DC: Federal Judicial Center.

POSNER, Richard (1972) "The Behavior of Administrative Agencies," 1 Journal of Legal Studies 305.

PRIEST, George and Benjamin KLEIN (1984) "The Selection of Disputes for Litigation," 12 Journal of Legal Studies 1.

RABIN, Robert (1972) "Agency Criminal Referrals in the Federal System: An Empirical Study of Prosecutional Discretion," 24 Stanford Law Review 1036.

SHAPIRO, Martin (1975) "Courts," in F. Greenstein and N. Polsby (eds.), Handbook of Political Science, Vol. 5. Reading, MA: Addison-Wesley.

TRAYNOR, Roger J. (1970) The Riddle of Harmless Error. Columbus: Ohio State University Press.

WALKER, Jack (1969) "The Diffusion of Innovations among the American States," 63 American Political Science Review 880.

YALE LAW JOURNAL (1979) "Note: Courting Reversal: The Supervisory Role of State Supreme Courts," 87 Yale Law Journal 1191. 
HeinOnline -- 21 Law \& Soc'y Rev. 446 1987-1988 